\title{
Elements Influencing Dividends of Banks in the MENA Region
}

\author{
Fadi A. Ghosn \\ School of Business, Lebanese International University (LIU), Lebanon.
}

\begin{abstract}
Dividend Policy is crucial for every banking organization, since it aids in finding the market worth of the organization's capital, and it helps shareholders arrange their investment plans. By exploiting a sample data collected from 40 different banks across 8 different countries in the MENA region; covering a period of 7 years from 2011 till 2017; the study identifies, via regression analysis, the impact of financial leverage, investment expenditure, total assets, liquidity, capital adequacy, return on assets, and GDP on dividends. Dividend payout ratio and Ln dividends been used as dependent variables. The results show an insignificant model using dividend payout ratio as a dependent variable, since it has a high prob. F stat. of $74.64 \%$. While it shows a significant model using $\ln$ dividend as a dependent variable with a prob. F stat. of 0.000 , R-Squared value of $96.97 \%$. The size of the bank shows a significant positive effect on dividends paid, while other variables found to have insignificant impact.
\end{abstract}

Keywords: Banks, MENA, Dividends, Capital, Size, Assets, Investment, GDP, liquidity, financial leverage.

DOI: $10.7176 /$ RJFA/10-12-09

Publication date:June $30^{\text {th }} 2019$

\section{Introduction}

Dividend Policy, in simple terms refers to the framework followed by any organization in terms of the level of their earnings that they wish to distribute for shareholders in return for their investment. Dividend policy establishes the distribution of the bank's earnings among retention as money dividend payments to shareholders. Dividend policy is the method which management follows in making dividend payout choices, or even in other phrases, the size as well as pattern of money distributions within a time period to shareholders (Benito \& Young, 2001).

There is a reciprocal connection between dividends and retained earnings. Directors have to think about the selection of elements in determining dividend policy. Investors should keep a watch on the company's dividend policy for many business trends as the context of unusual earnings could be a warning signal. Hence, Dividend policy has a rather strong impact on the investor perception and on the image of the bank (Anil \& Kapoor, 2008). For investors that are looking for stocks with high performance and earning per share, lower dividend might imply future higher return on investment. Future prospects, expansion, diversification, and mergers are affected by dividend policy. Dividends and retained earnings are essential for buoyant, healthy capital system, and structure of the bank. Every organization, whether banking or non-banking, is required to have a dividend policy when it trades with public stock. The normal policy of an enterprise is retaining a portion of net earnings, and disperse the remaining amount to the shareholders where numerous variables need to be evaluated prior to developing a long-term dividend policy. (Osobov \& Denis, 2007)

Essentially, there are three theories on dividend policy. First is the "Dividend Irrelevance Principle", states that dividends do not have an impact on the bank's marker or book value. This particular principle is founded on the assumption that dividend is not a tax disadvantage for an investor, as well as banks are able to raise money in capital markets for brand new investments with least issuance expenses. The proponents of the next theory on dividend policy assume that dividends can be harmful as they have a tax disadvantage for average shareholder, as well as market/book value of the bank (Deshmukh, 2003). Dividends develop a tax disadvantage for investors that receive them when these investors are taxed a lot more seriously compared to cost appreciation (capital gains). As outlined by this particular viewpoint, dividend payments must lessen the measurable returns to stockholders after individual taxes. On the contrary, the third theory states that dividends are excellent and will boost the valuation of the bank (Hanifa, et al., 2018)

In recent years, dividend policies have been indicators of various strategies adopted by banks such as sustainable business operations, credit worthiness, investments, and expenditure plans as well as a match between expectations of shareholders and bank's ability to manage it. (Allen, et al., 2011).

\subsection{Research Problem}

Despite of various existing research in terms of how dividend policies are formed and impacted by various factors in banks, there is a gap of literature and research in terms of how dividends are projected across the Middle East and North Africa region. In addition, the existing research considering the factors affecting dividend payments in banks show debatable results. In addition, investors need to forecast the future dividend of banks' since it affects their decision in many ways. 
Dividend is highly important to any banking organization since it reflects the true value of the company through its future expected cash flows. Dividends are also an indication of the company's growth stage. Mature companies pay higher level of dividends. As opposed growing companies prefer to use their free cash flows for investment purposes or for development purposes. Therefore, since dividend payouts indicate variables of the firm in relation to its profitability, strength, liquidity, as well as the growth stage of the bank, it is necessary to study dividend policies of banks in MENA region to understand the dynamics of banking industry and the value delivered to shareholders.

\subsection{Research Objectives}

The study has the below listed objectives:

RO1) Analyze the influence financial leverage on dividends.

$\mathrm{RO} 2$ ) Analyze the influence of investment expenditure on dividends.

RO3) Analyze the influence of profitability on dividends.

RO4) Analyze the influence of size on dividends.

RO5) Analyze the influence of GDP on dividends.

\subsection{Research Hypotheses}

The following 5 hypotheses are tested in this study through quantitative analysis in the form of regression analysis.

H1: Banks' size affects its dividend payments.

H2: Banks' financial leverage affects its dividend payments.

H3: Countries' GDP growth affects its dividend payments.

H4: Banks' profitability affects its dividend payments.

H5: Banks' investment expenditure affects its dividend payments.

\section{Industry Overview}

Over the last decade, the global banking system has been extremely resilient. In the MENA region, it has been subject to strong growth given the multiple factors of the economy. Based on the banker's top thousand world banks ranking for 2018, total assets reached $\$ 124$ trillion, while return on assets (ROA) stood at $0.9 \%$. Similarly, tier one capital ratio as a proportion of assets rose to $6.7 \%$, significantly above the 2008 ratio, however the recovery since the financial crisis has not been uniform across the world. US banks, compared to their European counterparts, are ahead on several measures. Aggressive policy interventions and forceful regulations helped propel US banks to recuperate more quickly (I.Jabbouri, 2016). Hence, the banking sector from across the world comprises a major industry that performs various supporting functions, as well as it adds strong value to any economy. MENA region is witnessing an increasing level of growth due to economic activity; production and the rise of the service sector, banking organizations have been highly profitable and successful on multiple parameters and have been able to pay out higher level of dividends to stockholders. Further, the banking sector of the MENA region has functioned as a strong support source allowing various economic activities, considerably new in this region, to function without interruptions and have led multiple cities transforming into international hubs and attractive investment, expansion, and development places from across the world.

\section{Literature Review}

Dividends are strongly influenced by various financial variables from the internal and external environment of the bank. An overall choice for money dividends regardless of the elimination of various tax rates among capital gains as well as dividend income have been perceived based on prior scientific studies. Dividends are utilized by shareholders to analyze the quality of the bank's money flows (Mardani, et al., 2018). Managers use money dividend announcements to signal changes in the expectations of future prospects of the bank. Dividends are able to convey info regarding the future or current amount of earnings. On the other hand, some empirical scientific studies suggest that dividends are not good predictors of the bank's future earnings (Manzoor, 2015)

Retention Ratio is a factor liked to dividend policies. It provides an understanding as to how much the bank wants to retain as a part of its earnings (Osobov \& Denis, 2007); thus it provides an understanding of how the dividend payout ratio of the bank would look like. Investors fall into several groups as income, age, and tax brackets, where supervisors must follow a $100 \%$ retention policy to evade conflict with shareholders, thus minimizing the concern of the excessive tax (double taxation) attracted by dividend earnings, and minimizing the transaction costs which creates the policy of a luxury, and harmful NPV (Hanifa, et al., 2018).

Dividends may be utilized in minimizing the agency issue involving stockholders as well as supervisors. (Al-Ajmi \& Abo Hussain, 2011) States that dividends are actually a technique of aligning managers' interest with those of investors, as well as providing agency price explanations of dividends. Another study indicates that the higher internal managerial control and ownership the bank select, the lower are the levels of both debt as well 
as dividends. The results suggest that the influences of profitability, growth, and dividend policy support an altered "pecking order" theory. Banks favor a particular level of stableness in dividend payments. Consequently, a good connection is anticipated between the ratios of net growth rate to total assets as well as dividend payout. The study adds that liquidity is actually a crucial determinant of dividend payout policy in advanced markets of US and Europe (Kuo, et al., 2013).

Banks with higher fixed charges as interest payments pay lower dividends in order to stay away from outside financing through inner financing (retained earnings). Leverage creates fixed costs, it could be said that banks make use of debt much more often compared to equity when raising outside capital (Allen, et al., 2011). Hence, dividend payout ratio is adversely related to the bank's beta coefficient that measures the risk associated with the bank. Bank size assessed using the log of overall assets can also be employed as proxy for the prices of external debt financing. A rather direct and positive connection is actually anticipated between size as well as dividend payout since bigger companies face lower issuing costs (Malavia Mardani \& Khusniyah Indrawati, 2018). The variability in capital design and structure suggests that bank's potential to have better access to capital markets, since banks will have the ability to swap between equity and debt and then take advantage of lower transaction costs. This particular scenario provides for higher and stable dividend payments. It is also examined that there exist a strong direct connection between dividend payout and variability in capital structure. (Guyot, et al., 2014)

Dividend payout ratio is positively related to the fraction of ownership of external shareholders in the bank, since external shareholders demand more dividends. If the external shareholders proportion of ownership is actually much less than internal ownership, then agency expense is actually reduced and the bank pays lower dividends (Malavia Mardani \& Khusniyah Indrawati, 2018). Stability of cash flows in the bank may be related to dividend payout. Cash flow variability is calculated when the ordinary least squares estimation of the coefficient of variation of money flows for a period of three financial years, where an inverse relationship is noticed between dividend payments and cash flow variability. With regard to managerial considerations, it has been seen through studies that there can be found a relationship between financial slack as well as dividend payout. Banks have a tendency to increase the financial slack of the company to be able to keep and maintain the power to undertake profitable as well as successful investments, therefore reducing dividend payments (Khang \& King, 2006). Financial slack is indirectly related to dividend payout ratio. Liquidity is a crucial determinant of dividend choice; if a business has sufficient cash flows, it would highly prefer to distribute money dividends. Profitability could additionally be related to dividend choice; higher the profitability of businesses, higher would be the propensity to offer dividends.

(Khang \& King, 2006) Supports the relationship for the transaction cost/residual concept of dividends, pecking order argument in addition to the functionality of dividends in mitigating agency difficulties. The study additionally finds that banks with financial flexibility to maintain stable dividends pay larger dividends. The tax clientele argument postulated by studies explains that investors falling in very low tax brackets favor top dividend paying stocks. (Adaoglu, 2000)

Long term debt has a negative impact on the dividend policy (Salminem, 2017). Additionally, it includes that agency expenses drop as dividend payout is elevated but at exactly the same time the transaction fees of financing increases. In such a situation an optimal expense can easily be derived at a lower dividend payout ratio. The unit outcomes of the study suggest that dividend payout is adversely related to the bank's past and anticipated long term growth rate of product sales, and beta coefficient of risk, as well as, considerably positively related to the number of stock holders. (Benito \& Young, 2001)

\section{Data Collection Method}

The data collection method mainly involves identification of prominent banks across the MENA Region in terms of the different identified variables. The data is identified for seven years during 2011-2017 and is tabulated in an excel format to ensure consistency and systematic analysis. Hence, the data collection method was mainly secondary data.

The sample size chosen for the data collection represents 5 banks from each of the 8 countries in the MENA region thus totaling 40 banks and 280 observations. Eight variables were identified and extracted from the banks' published financial reports: Total assets, intangible assets, total equity, total debt, net loans payable, dividends, and income along with the GDP growth of the 8 chosen countries. These variables were used as the base data to develop ratios mainly: financial leverage, investment expenditure, liquidity, capital adequacy, return on equity, return on assets, and dividend payout ratio for each of the banks across the 7 years. Ratios are tabulated and calculated through excel functions.

The computed ratios are then used as a base for further regression analysis in the study. The data collected is tested for its accuracy and is clear of any extreme observable errors in the study to achieve a normal distribution as well as to avoid the possibility of inefficient results. The eight countries selected for the study are as follows: United Arab Emirates, Lebanon, Saudi Arabia, Egypt, Iran, Kuwait, Qatar, and Bahrain 


\section{Research Method}

The data used in this study is 'balanced' panel data as every panel member (independent variable in this case) is observed for each year in the study. Regression analysis is the most suitable for this study, where the panel data EGLS Analysis and the panel least square methods have been major tools in the development of the data sets into an acceptable regression model. The methods are used both in the form of random effects and fixed effects models to suit the needs, and to ensure that a reliable and efficient model is developed for final analysis. Hence, the equation that is chosen for the study and developed for the final regression model analysis is presented below.

$$
\text { LNDIVID = C (1) *FINLEVER + C (2) *GDPG + C (3) *INVESTEXPEND + C (4) *LNASSETS + C (5) }
$$

$$
* \mathrm{ROA}+\mathrm{C}(6)+[\mathrm{CX}=\mathrm{F}]
$$

\section{Regression Analysis Variables}

The hypotheses in the study are tested using regression analysis by taking dividend payout ratio and dividends in its log form as the dependent variables one by one, and by considering the following variables as independent variables:
1. Total assets in its $\log$ form
2. $\quad$ Financial leverage ratio (Total Debt/Total Equity)
3. ROA (Net Income/ Average Total Assets)
4. Capital adequacy (Total Equity/Total Assets)
5. Liquidity (Loans/Assets)
6. GDP growth
7. Investment expenditure (Intangible Assets/Total Assets)

\section{Findings and Results}

\subsection{Correlation Matrix}

As indicated in the correlation matrix (table1), independent variables do have a considerable correlation with the dependent variable in the study. Also there exists a strong correlation between two chosen independent variables for the study: Capital Adequacy Ratio and Liquidity of the Banks at $76.32 \%$, and a high correlation between them and other variables. Hence, in order to avoid the situation of Multi-Collinearity, wherein the base assumptions for regression analysis would be violated, the two variables have been eliminated from the matrix and are not a part of the further advanced analytical tools.

Table 1 . Correlation Matrix

\begin{tabular}{|l|c|c|c|c|c|c|c|c|}
\hline & DPR & FINLEVER & GDPG & $\begin{array}{l}\text { INVEST } \\
\text { EXPEND }\end{array}$ & LIQUIDITY & LNASSETS & ROA & $\begin{array}{c}\text { CAP } \\
\text { ADEQ }\end{array}$ \\
\hline DPR & 1.000000 & & & & & & & \\
\hline FINLEVER & 0.017346 & 1.000000 & & & & & & \\
\hline INDPG & -0.022059 & -0.087782 & 1.000000 & & & & & \\
\hline LIQUIDITY & 0.142335 & -0.123056 & 0.021989 & 1.000000 & & & & \\
\hline LNASSETS & -0.127351 & -0.110985 & 0.019616 & 0.881505 & 1.000000 & & & \\
\hline ROA & -0.024644 & -0.058975 & -0.022570 & -0.483607 & -0.438373 & 1.000000 & & \\
\hline CAPADEQ & 0.100723 & -0.107462 & 0.005860 & 0.706302 & 0.763297 & -0.375694 & 0.029780 & 1.000000 \\
\hline
\end{tabular}

Source: Prepared by Author

\subsection{Panel data analysis, Random model}

The research starts by using the dividend payout ratio as the dependent variable, where it obtains a prob. Of $\mathrm{F}$ statistic around $74.64 \%$, accepting the null hypothesis that all the independent variables may be zero with a probability of $74.64 \%$, which means that the whole model is insignificant. Hence, the data set for the study would be tested using a fixed effects model to improve the accuracy and identify if there exist any endogenous variables (Chmelarova, 2007). As indicated by Hausmann test, the probability value is 0.5227 implying that is higher than the set p-value of 0.05 and hence is a restriction from developing the model using the fixed effects analysis. Hence, the model cannot be proceeded with, and the fixed effect model cannot be performed.

\subsection{Introducing Ln of Dividends and Random Effects Model}

The next step is to alter the dependent variable from dividend payout ratio of the banking organizations chosen to the dividends paid in its log form on a yearly basis; which is used from this stage and throughout the research as the dependent variable. One of the major benefits of using $\mathrm{Ln}$ of the dependent variable is that it allows for a non-linear as compared to a more complicated linear equation and quite generalized equation for the study that is easy to identify and deploy in order to get accurate results (Benoit, 2011). Taking Ln value of dependent 
variables as well as the Ln of assets as one of the independent variables, allow for a better interpretation since the elasticity of an independent variable in relation to the dependent variable is expressed through the log terms. Another benefit of taking Ln of the dependent variable, in this present study is for the heteroscedasticity aspect of the study with its level of variance between the values of the data set, usually non-beneficial or detrimental to the quality of the regression model (Chen, et al., 2014). Lastly, using the Ln of dependent and independent variables allows the data set to have a more normal error rate. As noted through the results, the data set is rather positively skewed and present abnormal errors.

Using the new dependent variable in its log form, the data is tested once again using the random effects model in terms of the panel data EGLS Analysis. The number of cross sections taken for the study, time periods in the form of years as well as the number of observations remain the same.

Table 2. Initial Random Effects Model

\begin{tabular}{lrrrr}
\hline \hline \multicolumn{1}{c}{ Variable } & Coefficient & Std. Error & t-Statistic & Prob. \\
\hline \hline FINLEVER & -0.011139 & 0.006050 & -1.841192 & 0.0667 \\
GDPG & -0.002471 & 0.010805 & -0.228697 & 0.8193 \\
INVESTEXPEND & 0.132801 & 0.033079 & 4.014680 & 0.0001 \\
LNASSETS & 0.710581 & 0.060169 & 11.80967 & 0.0000 \\
ROA & $2.13 \mathrm{E}-05$ & 0.000527 & 0.040389 & 0.9678 \\
C & -0.001655 & 1.080380 & -0.001532 & 0.9988 \\
\hline \hline & Weighted Statistics & & 1.968258 \\
& 0.335500 & Mean dependent var & & 0.685514 \\
R-squared & 0.323374 & S.D. dependent var & & 87.12280 \\
Adjusted R-squared & 0.563885 & Sum squared resid & & 1.371500 \\
S.E. of regression & 27.66799 & Durbin-Watson stat & & \\
F-statistic & 0.000000 & & \\
Prob(F-statistic) & & & \\
\hline \hline
\end{tabular}

Source: Prepared by Author

In terms of the R-Square and Adjusted R-Square values, the results have increased to $33.50 \%$ and $32.33 \%$ respectively implying a better explanation of the variance of the dependent variable as explained by the independent variables. In addition to this, the Prob (F) statistic is 0.00 for this model implying that the null hypothesis is rejected since there is no possibility of any zero coefficients of the independent variables being present in the study. Completing these good results, it is now possible to proceed with the Haussmann Test again.

\subsection{Haussmann Test}

The Haussmann test model (table 3 ) gives a result of 0.0075 , so the $p$ value is less than the set $p$-value, 0.05 . The null hypothesis that the random effects is appropriate is rejected and we have to go to the fixed effects model

Table 3. Hausmann Test for the initial model

\begin{tabular}{lcrr}
\hline Test Summary & Chi-Sq. Statistic & Chi-Sq. d.f. & Prob. \\
\hline \hline Cross-section random & 15.787449 & 5 & 0.0075 \\
\hline \hline
\end{tabular}

Source: Prepared by Author

\subsection{Fixed Effects Model-Panel Least Square}

The fixed effects model is a beneficial choice in the study since it gives reliable estimates. This fixed effects model is being developed with the dependent variable being Ln of the dividends paid using panel least squares method. With the same number of panel observations, cross-sections and periods, the results are more reliable in the following model (table 4). 
Table 4. Initial Fixed Effects Model

\begin{tabular}{lrrrr}
\hline \hline \multicolumn{1}{c}{ Variable } & Coefficient & Std. Error & t-Statistic & Prob. \\
\hline \hline FINLEVER & -0.009532 & 0.006137 & -1.553252 & 0.1217 \\
GDPG & -0.002080 & 0.010861 & -0.191505 & 0.8483 \\
INVESTEXPEND & 0.008874 & 0.048320 & 0.183660 & 0.8544 \\
LNASSETS & 0.749371 & 0.090587 & 8.272360 & 0.0000 \\
ROA & $-1.12 \mathrm{E}-05$ & 0.000528 & -0.021295 & 0.9830 \\
C & -0.590519 & 1.585706 & -0.372401 & 0.7099 \\
\hline \hline
\end{tabular}

Effects Specification

Cross-section fixed (dummy variables)

R-squared

Adjusted R-squared

S.E. of regression

Sum squared resid

Log likelihood

F-statistic

Prob(F-statistic)
0.954083 Mean dependent var

12.42092

0.945486 S.D. dependent var

2.368918

0.553102

Akaike info criterion

1.799677

71.89172

Schwarz criterion

2.383840

$-206.9548$

Hannan-Quinn criter.

2.033986

110.9754

Durbin-Watson stat

1.611542

\section{Source: Prepared by Author}

R-Squared and adjusted R-Squared $95.40 \%$ and $94.54 \%$ respectively demonstrates strong values implying that the chosen independent variables could be finally considered to have a significant influence on the chosen dependent variable, Ln dividends. In addition to this, as previously explained, the value of Prob. (F) Statistic is still 0.000 rejects null hypothesis and implying a good data fit for the regression model, and eliminating the possibility of all zero coefficients for the independent variables. Studies indicate that a complete 0.00 value is the best as it eliminates the need to inspect individual independent variables.

\subsection{Kurtosis and Skewness Level}

The next step in developing the regression model is the analysis of the normality levels in the graph developed. Hence, it can be said that the closer the Kurtosis level is to 0 , the more normal is the distribution of the data set known to be as mesokurtic distributions. Secondly, Kurtosis values lower than 0 indicates lighter weight to the tails and is known as platykurtic distribution (Westfall, 2014). Kurtosis values higher than 0 indicate heavier weights to the tails and hence is known as leptokurtic distribution. In the present study (figure 1), the Kurtosis value is quite high and is expected to indicate heavier weight to the tails at a value of 10.03 . Therefore, a higher level of Kurtosis in our study would mean that the data set has specific outliers that are bound to create the high level of variations and the presence of few residuals or outliers that need to be removed from the study. The histogram also provides an indication of the Skewness or the symmetry of the tails. As negative values for the skewness indicate left skewed data and positive values indicate right skewed data, a positive value in the present study of 0.018 indicates that the data is right skewed and has a rather heavier-tailed distribution.

As to the Jarque Bera value test, it has been done to confirm the normality of the study. One of the main reasons why this test has been used in this specific study is given the large data set and multiple values which can be only confirmed for their normality using this test. The test results mainly match the skewness of the data, which is usually acceptable at the rate of 0 for a symmetric distribution. The result of Jarque Bera test with a value of 577.2810 indicates that the errors in the study are not distributed evenly or normally across the graph. It can also be said that the data does not come from a normal distribution set. Hence, the high value of Jarque Bera in the study is an indication for the need to remove outliers and residuals in the study. 


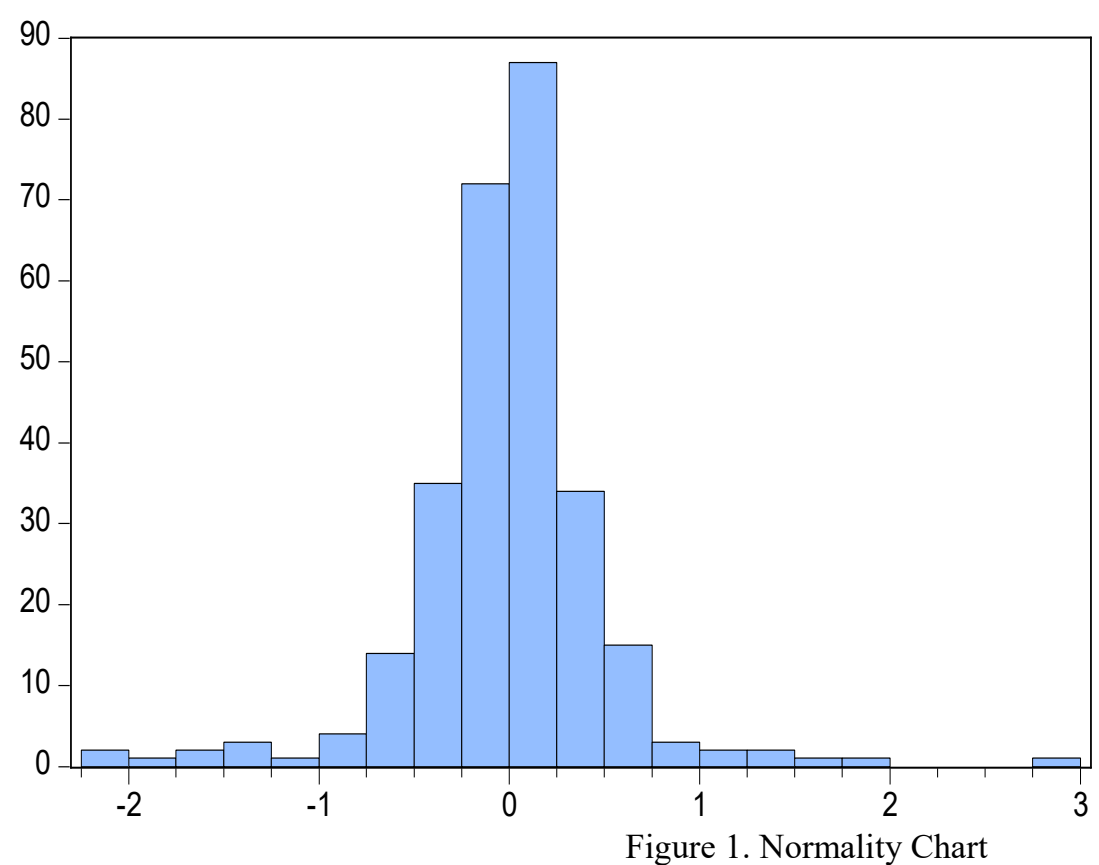

Series: Standardized Residuals

Sample 20112017

Observations 280

Mean

$-2.22 \mathrm{e}-17$

Median

Maximum

2.885233

Minimum

$-2.088658$

Std. Dev.

0.507618

Skewness $\quad 0.018155$

Kurtosis $\quad 10.03420$

Jarque-Bera $\quad 577.2810$

Probability $\quad 0.000000$

\subsection{Random Effects for Cleaned Model}

After removing outliers, the study conducts the panel data EGLS Analysis with the normal distribution values. It is important to note that this random effects model has a difference in the number of total observations from 280 to 247 and cross-sections changed from 40 to 36 indicating that 7 banks across different countries were removed from the study. The results of the study (table 5) in terms of the prob. (F) statistic indicate that it is at 0.00 . The low $\mathrm{p}$-value indicates that the data is more acceptable and fit the regression analysis model.

Table 5. Cleaned Random Effects Model

\begin{tabular}{lrcrr}
\hline \hline \multicolumn{1}{c}{ Variable } & Coefficient & Std. Error & t-Statistic & Prob. \\
\hline \hline FINLEVER & -0.002267 & 0.004755 & -0.476655 & 0.6340 \\
GDPG & -0.000398 & 0.008569 & -0.046433 & 0.9630 \\
INVESTEXPEND & 0.089959 & 0.029208 & 3.080007 & 0.0023 \\
LNASSETS & 0.646932 & 0.056483 & 11.45361 & 0.0000 \\
ROA & $-4.28 \mathrm{E}-05$ & 0.000407 & -0.105297 & 0.9162 \\
C & 1.077975 & 1.013043 & 1.064096 & 0.2884 \\
\hline \hline & \multicolumn{2}{l}{ Weighted Statistics } & & \\
\hline \hline & 0.344504 & Mean dependent var & & 1.397981 \\
R-squared & 0.330904 & S.D. dependent var & & 0.539131 \\
Adjusted R-squared & 0.432862 & Sum squared resid & & 1.472145 \\
S.E. of regression & 25.33206 & Durbin-Watson stat & & \\
F-statistic & 0.000000 & & & \\
Prob(F-statistic) & &
\end{tabular}

Source: Prepared by Author

\subsection{Haussmann Test - Hypothesis Development}

Due to the various alterations made in the study and the data set, it has been hypothesized that the value of $p$ in the Haussmann test would be lesser than 0.05 (Haussmann, 1978). Observation of the results in table 6 indicate that the probability value of the Haussmann Test is at 0.0041 implying that the null hypothesis is rejected and the fixed effect is most appropriate. 
Table 6. Haussmann Test for the Cleaned Random Effects Model

\section{Source: Prepared by Author}

\subsection{Fixed Effect Model- Panel Least Square Method}

The panel least squares method in the form of a fixed effects model is developed after clearing all the outliers. As presented in table 7, the F-statistic value for the model is as high as 165.1235 for the set p-value of 0.000 indicating a strong possibility of rejecting the null hypothesis. In addition to this, the hypothesis relating to the Durbin Watson statistic value is also proved true through the fixed effects model as the value is high at 1.75 as compared to previous fixed and random effects model, and is closer to 2 as well as within the normal levels. Lastly, the fixed effects model also indicates that the R-Squared and Adjusted R-Squared values are higher than as developed in previous models and is at $96.97 \%$ and $96.38 \%$ respectively; indicating that a high level of variance in the Ln Dividend, as dependent variable, can be explained through the independent variables. Lastly, looking at t-tests, only Ln Assets as an independent variable can be classified for having a considerable impact on the dependent variable, Since it has a t-statistic probability of 0.00 .

Table 7. Cleaned Fixed Effects Model using Panel Least Squares

\begin{tabular}{lrrrr}
\hline \multicolumn{1}{c}{ Variable } & Coefficient & Std. Error & t-Statistic & Prob. \\
\hline \hline FINLEVER & -0.001021 & 0.004794 & -0.213034 & 0.8315 \\
GDPG & -0.000191 & 0.008587 & -0.022213 & 0.9823 \\
INVESTEXPEND & 0.009391 & 0.036896 & 0.254521 & 0.7993 \\
LNASSETS & 0.687143 & 0.070795 & 9.706111 & 0.0000 \\
ROA & $-5.30 \mathrm{E}-05$ & 0.000407 & -0.130307 & 0.8965 \\
C & 0.434383 & 1.225259 & 0.354523 & 0.7233 \\
\hline \hline
\end{tabular}

Effects Specification

Cross-section fixed (dummy variables)

\begin{tabular}{lrlr}
\hline \hline R-squared & 0.969755 & Mean dependent var & 12.29810 \\
Adjusted R-squared & 0.963882 & S.D. dependent var & 2.222202 \\
S.E. of regression & 0.422326 & Akaike info criterion & 1.264392 \\
Sum squared resid & 36.74195 & Schwarz criterion & 1.846922 \\
Log likelihood & -115.1524 & Hannan-Quinn criter. & 1.498923 \\
F-statistic & 165.1235 & Durbin-Watson stat & 1.752279 \\
Prob(F-statistic) & 0.000000 & & \\
\hline
\end{tabular}

Source: Prepared by the Author

\subsection{Normality Graph}

The Normality Graph in figure 2, shows Kurtosis level, which was extremely high in the previous graph at 10.03, is reduced to 6.182, which is more near to 3, which is considered as the best level for most studies reviewed. A reduced level of Kurtosis indicates that the previously identified presence of extreme outliers or high value negative residuals impacting the quality of the study have been reduced. Hence, the weights of the tails are reduced in terms of their heaviness and provide a better idea of the normality of the distribution by the data set. In addition to this, another change observed is a drastic reduction in the value of Jarque Bera from 577.2810 to 104.856 indicating that the removal of residuals and extreme outliers has highly improved the data set and the reliability for the regression analysis model. 


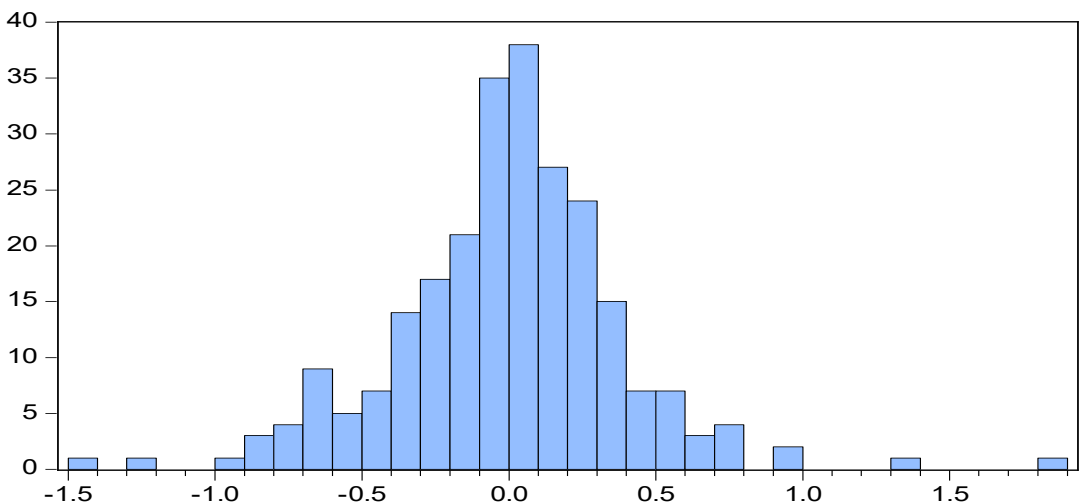

Series: Standardized Residuals Sample 20112017

Observations 247

\begin{tabular}{lr} 
Mean & \multicolumn{1}{c}{$2.61 \mathrm{e}-17$} \\
Median & 0.008821 \\
Maximum & 1.877759 \\
Minimum & -1.494844 \\
Std. Dev. & 0.386468 \\
Skewness & 0.123753 \\
Kurtosis & 6.182326 \\
& \\
Jarque-Bera & 104.8562 \\
Probability & 0.000000
\end{tabular}

Figure 2. Normality Chart for the Cleaned Model

\subsection{Residuals Value}

Lastly, the data analysis step involves identifying the value of the residuals. As seen from the graph, it can be identified that the value of residuals lies between 2 and -2 which indicates a considerable change from the previous residual graphs that exceeded the values of -3 and 3 . A low value of residuals indicates that the values are closer to the regression data line and are incorrect only by minimal variance level.

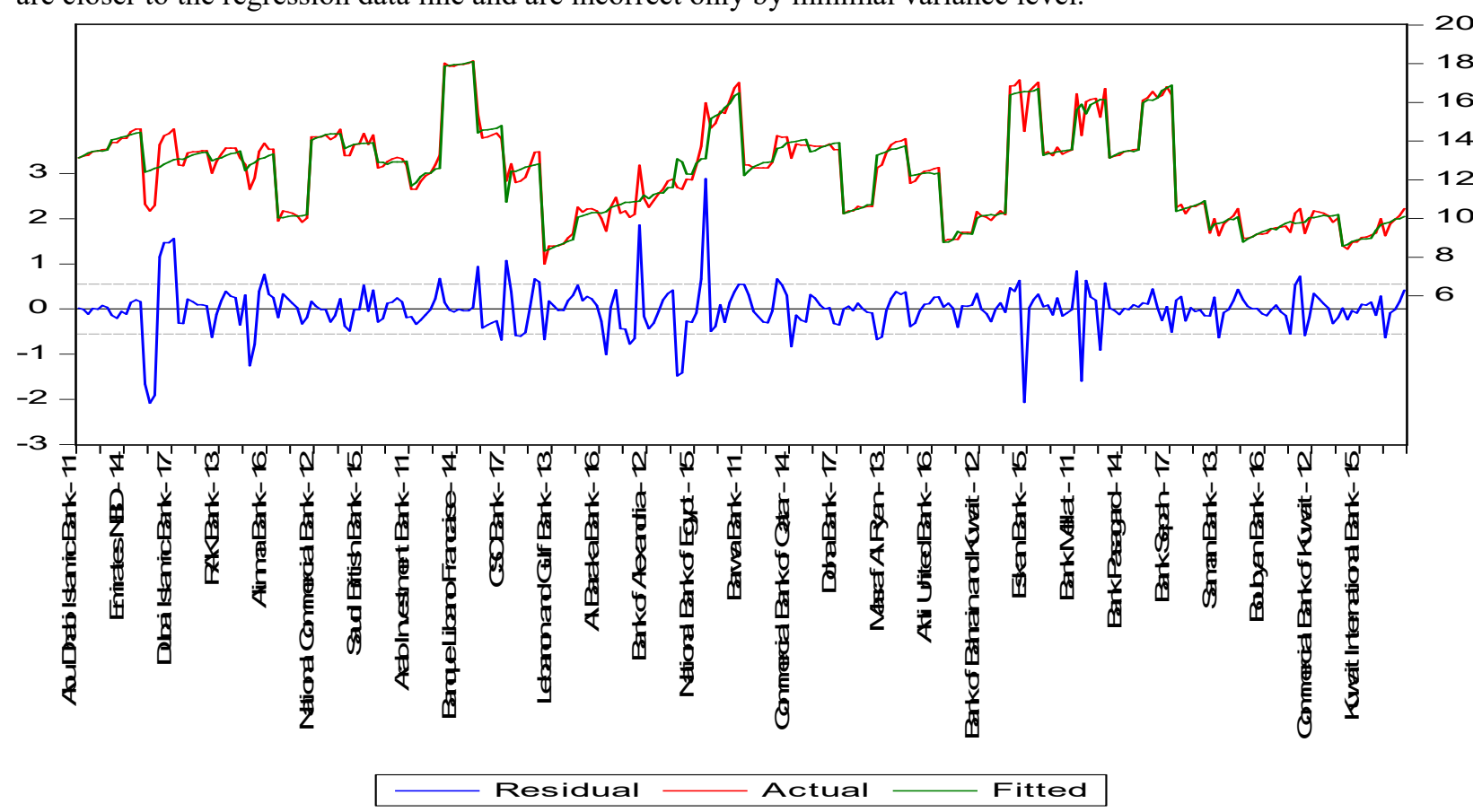

Figure 3. Residuals Chart for the Cleaned Model

\subsection{Overall Results and Hypotheses Confirmation}

To conclude the data analysis, it can be said that only the first hypothesis can be accepted, where total assets expressed in the form of Ln assets, has a positive correlation with the dividends paid expressed in the form of $\mathrm{Ln}$ dividends; which means a $1 \%$ change in assets results in a $0.68714 \%$ change in dividends.

Observations of the results in terms of $t$-values of the independent variables in the study indicate different values and hence require different interpretations. Investments' expenditure, in the final fixed effects model indicates a t-value of 0.254 implying that although the sample results for this parameter rejects the null hypothesis, the value is low and closer to zero indicating that there is a possibility for its acceptance. Similar interpretation can be said as to the situation of financial leverage where the t-value is -0.213 , GDP at -0.022 and ROA at -0.13 , with a probability more than 0.05 . Hence, null hypothesis is rejected, and variables do not have significant effect of dividends.

LNDIVID $=-0.00102 *$ FINLEVER $-0.00019 *$ GDPG + 0.00939*INVESTEXPEND + 0.68714*LNASSETS $0.00005 * \mathrm{ROA}+0.43438+[\mathrm{CX}=\mathrm{F}]$ 


\section{Conclusion and Recommendations}

The study examined dividend policies of different banks in the MENA region. This region has been strongly growing in economic and social terms in the recent years. Hence, the study choses 40 most prominent banks across 8 countries in the MENA region that have a considerably different environment in terms of their political, social, economic and financial instability and thus totaling 280 observations. The study was developed through multiple statistical tests and analysis, as well as, consistent confirmation and elimination of variables that either fit or unfit the study.

The aim of the research is to identify the different variables that have a considerable level of influence on the dividend of banks represented by dividend payout ratio and dividends in its log form. For this purpose, 5 major hypotheses were identified linking dividends paid by the banking organization to investment expenditure ratio, total assets in its log form, financial leverage, GDP growth of the country within which the bank is operating, and return on assets.

The study showed that dividend payout ratio could not represent the dependent variable since the prob. F. stat for the model was high of $74.64 \%$ so that the overall model is not significant.

Replacing the dependent variable by $\mathrm{ln}$ of dividends showed much better significant model with a prob. $\mathrm{F}$ stat. of 0.000. After eliminating outliers, Hausmann test indicated the rejection of the null hypothesis and the need to use of the fixed effect model, thus resulting in a high R-squared value of $96.97 \%$, which is an indication that the five variables chosen collectively defines $96.97 \%$ percentage variation in the dividends of the banking organization.

Although a variance value and a correlation was determined for each of the independent variables identified, only the relationship between size and dividends paid had a statistically significant positive value. As for other variables and by looking at the t-stat., they all reject the null hypothesis and showed insignificant effects on the dividend. The effect is positive for investment expenditure, yet it is negative for all other variables.

For further researches, we recommend studies to cover bigger data samples from prominent banks that have the highest volume of equity capital. This would allow for a clearer understanding of what the majority of the equity shareholders in the region are receiving in terms of their investments in the capital of prominent banking organizations. We also recommend the use of different time frames like quarterly data. In addition to this, we recommend using primary data through the interaction with the banking professionals in these countries in order to gain a first-hand understanding of how they decide their dividend policies, and what other variables whether quantitative or behavioral can affect future dividend payments. This would better clarifies the relationship that certain variables have with the dividends paid by these banking organizations; it also provides an empirical evidence and supporting statements directly from the organizations under study.

\section{References}

Baker, H., Powell, G. \& Veit, E., 2002. Revisiting the dividend puzzle.. Review of Financial Economics, 11(4), pp. 241-261.

Adaoglu, C., 2000. Instability in the Dividend Policy of the Istanbul Stock Exchange (ISE) Corporations: Evidence from an Emerging Market. SSRN Electronic Journal.

Akossou, A., 2013. Impact of data structure on the estimators R-square and adjusted R-square in linear regression.. University of Parakou Publication.

Al-Ajmi, J. \& Abo Hussain, H., 2011. Corporate dividends decisions: evidence from Saudi Arabia.. The Journal of Risk Finance, 12(1), pp. 41-56..

Allen, F., Bernard, A. \& Welch, I., 2011. A Comment on 'A Theory of Dividends Based on Tax Clienteles'.. SSRN Electronic Journal., pp. 15-22.

Amidu, M. \& Abor, J., 2006. Determinants of dividend payout ratios in Ghana.. The Journal of Risk Finance, 7(2), pp. 145-156.

Anil, K. \& Kapoor, S., 2008. Relevance of Signaling and Smoothing Approaches to Dividend: A Study of Indian IT Sector.. Asia Pacific Business Review, 4(4), pp. 104-123.

Balanda, K. P., 1988. Kurtosis: A Critical Review. American Statistician, pp. 111-119.

Bell , A., Fairbother, M. \& Jones, K., 2019. Fixed and Random effects models: making an informed choice. Quality and Quantity, 53(2), p. 1051-1074.

Benito, A. \& Young, G., 2001. Hard Times or Great Expectations? Dividend Omissions and Dividend Cuts by UK Firms.. SSRN Electronic Journal.

Benoit, K., 2011. Linear Regression Models with Logarithmic Transformations. Methodology Institute - London School of Economics.

Bitar, M., Saad, W. \& Benlemlih, M., 2016. Bank risk and performance in the MENA region: The importance of capital requirements. Economic Systems.

Chen, T., Lu, N., Feng, C. \& Hongyue, W., 2014. Log-transformation and its implications for data analysis. Shanghai Archieves of Psychiatry, 26(2), pp. 105-109. 
Chen, Y., 2016. Spatial Autocorrelation Approaches to Testing Resdiuals from Least Squares Regression. PLoS One.

Chmelarova, V., 2007. The Hausman Test, and Some Alternatives, with Heteroskedastic Data.. Louisiana State University and Agricultural \& Mechanical College.

Deangelo, L., Deangelo, H. \& Stulz, R., 2006. Dividend policy and the earned/contributed capital mix: a test of the life-cycle theory. Journal of Financial Economics, 81(2), pp. 227-254.

Deshmukh, S., 2003. Dividend Initiations and Asymmetric Information: A Hazard Model.. The Financial Review, 38(3), pp. 351-368.

Dewasiri, N. \& Yatiwell, W., 2006. Why Do Companies Pay Dividends? A Comment.. SSRN Electronic Journal.

Distinguin, I. \& Rugementiwari, C., 2011. The Role of Market Discipline on Bank Capital Buffer: Evidence from a Sample of European Banks.. SSRN Electronic Journal.

Faccio, M., Lang, L. \& Young, L., 2001. Dividends and Expropriation.. American Economic Review, 91(1), pp. 54-78.

Ghodrati, H. \& Ghazi, F. S., 2014. Stock market liquidity and firm dividend policy: Evidence from Tehran Stock Exchange.. Management Science Letters, 4(8), pp. 1849-1858.

Guyot, A., Lagoarde-Segot, T. \& Neaime, S., 2014. Foreign shocks and international cost of equity destabilization. Evidence from the MENA region.. Emerging Markets Review, 18(1), pp. 101-122.

Hanifa, H., Hamdan, M. \& M, H., 2018. Dividend policy in the banking sector in G-7 and GCC countries: A comparative study.. Risk Governance and Control: Financial Market and Institution, 8(3), pp. 70-79.

Haussmann, J., 1978. Specification tests in econometrics.. Econometrica, Volume 46, p. 1251-1271.

I.Jabbouri, 2016. Determinants of corporate dividend policy in emerging markets: Evidence from MENA stock markets.. Research in International Business and Finance, Volume 37, pp. 283-298.

Ibe, I. G., 2016. The impact of external financing on dividend per share. Journal of Applied Finance and Banking, 6(3), pp. 39-53.

Idawati, W. \& Wahyudi, A., 2015. Effect of Earning Per Shares (EPS) and Return On Assets (ROA) against Share Price on Coal Mining Company Listed in Indonesia Stock Exchange. Journal of Resources Development and Management, Volume 7, pp. 79-90.

Jung-Yeo, H., 2018. Role of free cash flows in making investment and dividend decisions. The Asian Journal of Shipping and Logistics, 34(2), pp. 113-118.

Kapoor, S., Mishra, A. \& Anil, K., 2010. Dividend Policy Determinants Of Indian Services Sector: A Factorial Analysis.. Paradigm, 14(1), pp. 24-41.

Kato, H., Loewenstein, U. \& Tsay, W., 2002. Dividend policy, cash flow, and investment in Japan.. PacificBasin Finance Journal, 10(4), pp. 443-473.

Kent Baker, H. \& Powell, G., 2012. Dividend policy in Indonesia: survey evidence from executives.. Journal of Asia Business Studies, 6(1), pp. 79-92.

Kent Baker, H., Saadi, S., Dutta, S. \& Gandhi, D., 2007. The perception of dividends by Canadian managers: new survey evidence.. International Journal of Managerial Finance, 3(1), pp. 70-91.

Khang, K. \& King, T., 2006. Does Dividend Policy Relate to Cross-Sectional Variation in Information Asymmetry? Evidence from Returns to Insider Trades.. Financial Management, 35(4), pp. 71-94.

King, L. M. \& David, H. C., 1995. The application of the durbin-watson test to the dynamic regression model under normal and non-normal errors. Econometric Reviews, 14(4), pp. 487-510.

Kuo, J., Philip, D. \& Zhang, Q., 2013. What drives the disappearing dividends phenomenon?.. Journal of Banking \& Finance, 37(9), pp. 3499-3514.

Malavia Mardani, R. \& Khusniyah Indrawati, N., 2018. Ownership Structure, Corporate Governance and Dividend Policy: Evidence from Indonesia.. KnE Social Sciences, 3(10).

Manzoor, H., 2015. Impact of Dividends Announcements on Stock Returns Evidence From Karachi Stock Market. American Research Journal of Business and Management, 1(2), pp. 25-36.

Mardani, R. M., Moeljadi, Sumiati \& Indrawati, N. K., 2018. Ownership Structure, Corporate Governance and Dividend Policy:Evidence from Indonesia. s.1., s.n., p. 1249-1255.

Mostafa, S., 2017. Liquidity Risk in the MENA Region Sector:Does Bank Type Make a Difference?. Journal of Developing Areas, pp. 1548-2278.

Mrad, F. \& Mateev, M., 2018. Banking System in the MENA Region: A Comparative Analysis between Conventional and Islamic Banking in the UAE. Conference: 2nd AUE International Research Conference.

Osobov, I. \& Denis, D., 2007. hy Do Firms Pay Dividends? International Evidence on the Determinants of Dividend Policy.. SSRN Electronic Journal.

Salminem, 2017. Impact of Dividends Announcements on Stock Returns Evidence From Karachi Stock Market.. American Research Journal of Business management.

Westfall, P. H., 2014. Kurtosis as Peakedness, 1905-2014. RIP. American Statistician, 68(3). 